essentials as staffing, allocation of effort, budgets and research progress, as well as providing a service to the working scientists.

\section{Conference on Ergonomics}

THE annual conference of the Ergonomics Research Society will be held at the Collcge of Technology, Loughborough, during April 9-12. Subjects under discussion will include: comparative effects of alcohol or caffeine addition to water on the physiological and psychological tolorance to work in a warm-dry environment; the design of ventilated heat-protected clothing for use in industry; stages in the acquisition of industrial skill; the learning of advance cues in process control; the teaching of orgonomies; ergonomic studies in industry; studies on motor vehicle seating; the role of seating in the application of manual control forces; teaching machines in industrial and military training; physiological methods of studying light muscular work; electronic equipment for laboratory and field studies in ergonomics; fixing rest allowances for static muscular work; effect of anoxia on the accuracy of setting of machine tool controls by acclimatized subjects at altitudes abovo $13,000 \mathrm{ft}$.; equipment design-a case study; meeting-points of sociopsychological analysis and ergonomies in the industrial situation; the nature of athletic skill. Further information can be obtained from the secretary, Dr. S. Griew, Department of Psychology, University of Bristol, 22 Berkeley Square, Bristol 8.

\section{The Worshipful Company of Gardeners' Scholar- ship}

Apprircatrons are invitod for a scholarship spon. sored by the Worshipful Company of Gardeners, and open to young gardeners who are undergoing or have completod training at the Royal Horticultural Society's Gardens, Wisley, or elsewhere, and who will have had at loast four yoars' practical exporionco in horticulturo by October 1, 1962. Under present conditions the scholarship is restricted to malo candidates who are unmarried and undertake to romain so during the tenure of the scholarship. The scholarship will be tenable for two years, boginning October 1, and is valued at $£ 300$ per annum. Applications should be made in writing to the Secretary, Royal Horticultural Society, Vincent Square, London, S.W.1, not later than May 31.

\section{Announcements}

Prof. W. F. Cassie, professor of civil engineering in the University of Durham (King's Collogo, Nowcastle upon Tyno), has boon appointed chairman of the Resoarch Advisory Committee of the Cement and Concrete Association. Other members of tho Committee are: C. L. a'Court, Prof. A. L. L. Baker, R. H. Bates, F. M. Bowen, P. A. Fitzpatrick, A. Goldstein, Dr. M. F. Kaplan, R. A. Kidd, W. K. Laing, Dr. A. R. Lee, Dr. L. J. Murdock, Prof. J. H. Nappor, Dr. T. W. Parker, Clive Pascall, P. T. Pattorson and J. L. Womersley.

Imperial Chemical Industries, Titn, publishers of Endeavour, are offering prizes totalling 100 guineas for cssays on the following subjects: the determination of chemical structure; recent progress in solid. state physics; the age of the universe; the human oyo; free radicals; the naturo of viruses. Further information can be obtained from the Deputy Secretary, British Association for the Advancoment of Science, 3 Sanctuary Buildings, Great Smith Street, London, S.W.1.

THe Paul Instrument Fund Committeo has made a grant of $£ 17,250$ to Dr. R. F. Richards, Fellow of Lincoln College, Oxford, and university domonstrator in chemistry, for the construction of apparatus to excite electron and nuclear resonancos simultanoously in the same material oporating at high field strength and with measurement of small line-widths. The Paul Instrument Fund Committee, composod of representatives of the Royal Society, the Institute of Physics and the Physical Society and the Institution of Electrical Engineers, was set up in 1945 "to receive applications from British subjects who are research workers in Groat Britain for grants for the design, construction and maintenance of novol, unusual or much improved typos of physical instruments and apparatus for investigations in pure or applied physical scionce".

THE tenth annual general meeting and conforence of the British Agricultural History Society will be held in Sidney Sussex College, Cambridge, during April 11-13. Further information can be obtained from Miss F. H. Whetham, School of Agriculture. Cambridge.

The fourth rubber technology conference, organized by the Institution of the Rubbor Industry, is to be held at Church House, Westminster, during May 22-25. Further information can be obtained from Mr. P. D. Patterson, Dunlop Research Centre, Birmingham 24.

A MEeTing of the Pbotobiology Group to discuss "Radiation Measuremont in Biological Research" will be held at the National Physical Laboratory. Teddington, Middlesex, on April 10. Further information can be obtained from Dr. S. Y. Thompson. National Institute for Research in Dairying, Shinfield. Berks.

THE eleventh intornational conferonce on "HighEnergy Physics", sponsored by the International Union of Pure and Applied Physics, is to bo held at CERN, Geneva, during July 4-11. Further information can be obtained from E. W. D. Steel, Scientific Conference Secretariat, CERN, Geneva 23.

THE fiftieth anniversary of the South African Chemical Institute is to be celebrated during July 2-11. Various meetings and functions will be held in the Johannesburg, Pretoria and Vereeniging areas. Further information can bo obtained from the Secretary, South African Chemical Institute, P.O. Box 3361, Johannosburg.

AN intornational symposium on "Carbohydrate Chemistry", sponsored by the Chemical Socioty in conjunction with the University of Birmingham, will be held in Birmingham during July 16-20. Furthor information can be obtained from Dr. A. B. Foster, Chomistry Department, University of Birmingham, Edgbaston, Birmingham.

THE fourth international symposium on "Gas Chromatography", organized by tho AnalyticalChemical Division of the Gesellschaft Deutscher Chemiker and the Gas Chromatography Discussion Group under the auspices of the Hydrocarbon Research Group of the Instituto of Petroleum, is to be held in Hamburg during June 13-16. Further information can be obtained from Dr. W. Fritsche. Gesellschaft Deutschor Chemikor, Postfach 9075, Frankfurt (Main). 